\title{
Estimation of Groundwater Recharge Using Tracers and Numerical Modeling in the North China Plain
}

\author{
Qinghua Wu ${ }^{1,2, *}$, Guiling Wang ${ }^{2}$, Wei Zhang ${ }^{1}$, Haodong Cui ${ }^{1}$ and Wei Zhang ${ }^{2}$ \\ 1 Changjiang River Scientific Research Institute, Wuhan 430010, China; zhangwei@mail.crsri.cn (W.Z.); \\ cuihd@mail.crsri.cn (H.C.) \\ 2 Institute of Hydrogeology and Environmental Geology, CAGS, Shijiazhuang 050805, China; \\ guilingw@163.com (G.W.); zhangwei1306@126.com (W.Z.) \\ * Correspondence: wqh0505@126.com; Tel.: +86-27-828-20385
}

Academic Editor: Y. Jun Xu

Received: 10 May 2016; Accepted: 3 August 2016; Published: 18 August 2016

\begin{abstract}
Water resource shortage has been a serious problem since the 1980s in the North China Plain (NCP), resulting in plenty of environmental problems. Estimating the groundwater recharge rate accurately is vital for managing groundwater effectively. This study applied several methods, including chloride mass-balance, tracers (bromide and tritium) and numerical modeling (Hydrus-1D), to estimate groundwater recharge at three representative sites of the NCP: Zhengding (ZD), Luancheng (LC) and Hengshui (HS). The chloride concentration of the soil profile in the ZD site showed that the mean recharge was $3.84 \mathrm{~mm} /$ year with the residence time of 105 years for soil water transferring through the vadose area of $45.0 \mathrm{~m}$ in depth in the preferential flow model mainly. Considering the influence of preferential flow on the soil water movement in the field scale, the traditional methods (e.g., peak method of bromide and tritium tracers based on piston flow described in the literature) could be unsuitable to estimate groundwater recharge in the LC and HS sites, especially in areas with low recharge rates. Therefore, multi-region and mass balance methods were applied in this study. The results of this investigation showed that the mean values of recharge were 124.3 and $18.0 \mathrm{~mm} /$ year in the LC and HS sites, respectively, in 2010. Owing to complexity and uncertainty on the surface resulting from the measuring of evapotranspiration, the upper boundary of $1.4 \mathrm{~m}$ (under the ground where most of the plant roots did not reach) was chosen for the numerical modeling of Hydrus-1D, and the result showed that the mean recharge was $225 \mathrm{~mm} /$ year from 2003 to 2007, consistent with the result of tracers in the previous literature. The result also showed that the positive relation of groundwater recharge and the sum of irrigation and rainfall was presented in the spatial and temporal scale. Additionally, human activities promoted the recharge rate, and recharge rates increased with greater depths in the LC site generally. However, both cases did not appear clearly in the HS site, showing that the low penetrability of soil controlled the recharge rate in this site.
\end{abstract}

Keywords: North China Plain; groundwater; recharge; tracer; modeling

\section{Introduction}

Groundwater is a vital part of the water resources used for agriculture, especially for arid and semi-arid areas, such as the North China Plain (NCP). Since the 1980s, about $70 \%\left(9 \times 10^{4} \mathrm{~km}^{2}\right)$ of the total area was involved in the over-pumping of groundwater in the North China Plain, which resulted in many problems: a rapid decline of the groundwater level at a rate of 0.5 to $2.0 \mathrm{~m} /$ year, many cones of depression occurring in the main cities $\left(5.4 \times 10^{4} \mathrm{~km}^{2}\right)$, sea-water intrusion in the coastal area, the interface between salt water and fresh water declining in the middle of the east area and land subsidence in the coastal area [1,2]. Since the 1990s, the government of China recognized these serious 
problems, advising water-saving agricultural practices, such as drop irrigation, sprinkling irrigation, straw mulching and polythene mulching [3]. However, serious problems are still present, because the fast economic development of agriculture and industry needs more and more fresh water, most of which is pumped from ground aquifers. Therefore, effective management of groundwater is significant for the sustainable development of agriculture and industry in this area. In order to determine the safe yield of the groundwater, a reliable estimate of groundwater recharge is needed.

Since the mid-1980s, geological scientists have been interested in the study of groundwater recharge. Different methods were chosen to estimate groundwater recharge depending on the certain conditions of study areas, such as data types, land use, amount of recharge and the spatial and temporal scale. Common methods are water-balance, lysimeters, zero-flux plane, Darcy's law, the watertable fluctuation method, heat tracer, applied tracers $\left(\mathrm{Br}^{-}, \mathrm{I}^{-},{ }^{3} \mathrm{H}\right)$, historical tracers $\left({ }^{3} \mathrm{H},{ }^{36} \mathrm{Cl}\right)$, environmental tracers $\left(\mathrm{Cl}^{-}, \mathrm{NO}_{3}{ }^{-},{ }^{3} \mathrm{H},{ }^{18} \mathrm{O}\right.$ ), fluorescent tracers (rhodamine $\mathrm{WT}$, fluorescein) and the model method [4-6]. Over the last 20 years, the methods of tracing and modeling were considered as the most valuable methods in the world.

An environmental tracer, such as chloride, was used to estimate the groundwater recharge by the mean concentration of chloride below the rooting zone, supposing that the concentration of chloride keeps constant below the depth of the rooting zone. The sources of chloride, e.g., annual deposit (wet and dry) and quality of irrigation and fertilizer should be investigated exactly in the crop areas. The method was used and compared to other methods in many literature works, improving the understanding of groundwater recharge [7-12]. However, it is difficult to collect the data of chloride sources in long term.

Historical tracers $\left({ }^{3} \mathrm{H}\right.$ and $\left.{ }^{36} \mathrm{Cl}\right)$, resulting from human activities or historical events in the past, were used to estimate the groundwater recharge by the location of the tracers' concentration peak, assuming the piston flow for soil water [13]. Annual long-term recharge could be estimated, which is important to understand groundwater resources. However, the method may be limited by the depth of the groundwater level. The peak moved into the groundwater and disappeared in most of the North China Plain, especially in the crop areas where human events happened 50 years ago.

As the historical tracers, applied tracers are identified as a useful tool to estimate groundwater recharge, used as a pulse at the soil surface or underground. Main applied tracers were bromide, tritium and fluorescein dyes, which were successful and effective in estimating the groundwater recharge at present [14-17]. We should take note that the recharge calculated by the applied tracers is an average transport velocity based on Darcy's law. The liquid tracer was injected at some depth of soil with more than a $0.01 \mathrm{~m}$ error, which was not acceptable, and the liquid tracers are unsuitable when the recharge is very small (less than $20 \mathrm{~mm} /$ year). Additionally, different shapes of tracers' concentration distribution in the soil profile with the same depth of concentration peak should show different recharge rates. This method should be improved to investigate recharge exactly using the multimodal pore size distribution, the multi-penetrative model (multi-region) and the multilevel spline model $[18,19]$.

An alternative method to estimate the groundwater recharge is numerical simulation. Hydrus-1D has been used successively and widely to estimate soil hydraulic parameters by the global optimization method, soil water and solute movement and groundwater recharge [20-23]. In the field scale, the surface condition is too complicated to acquire exact data, such as evapotranspiration, soil evaporation and irrigation, which may make the model fail [24]. Choosing the depth below the rooting zone as the upper boundary of the model, with measuring of soil water content and potential in the long term, may solve this problem [25].

The main objectives of this study were to estimate the groundwater recharge in some representative areas of NCP by the chloride mass-balance method, the tracing method (bromide and tritium) and the Hydrus-1D model method, as well as to compare the results to each other. Additionally, we presented and discussed the relationship between groundwater recharge and land use, the injecting depth of tracers, the depth of the water level, irrigation and rainfall. 


\section{Site Description}

The study area is arid and semi-arid, with a monsoon-dominated climate in the NCP. The mean annual precipitation was $556 \mathrm{~mm}$ (1956-2003) [16], approximately 70\%-80\% between June and September, while the mean temperature and evaporation rate were $15^{\circ} \mathrm{C}$ and $1700 \mathrm{~mm}$ (1956-2000) [26], respectively. Economic crops (e.g., winter wheat, summer corn and cotton) were planted in most of the study area.

The NCP is comprised of three parts from west to east: the piedmont plain, the alluvial plain and the lacustrine plain. The groundwater flows from west to east. In the piedmont plain, the aquifer is unconfined, while unconfined (shallow layer) and confined (deep layer) in alluvial and lacustrine plains. The depth of groundwater was $50-70 \mathrm{~m}$ in the piedmont plain, $35-45 \mathrm{~m}$ and 3-10 $\mathrm{m}$ in the alluvial and lacustrine plains, respectively. From west to east, the lithology of the aquifer is mainly gravel in the piedmont plain, then the coarse sand-gravel in the alluvial plain and fine, medium and coarse sand in the lacustrine plain.

In this study, three representative sites (i.e., the Zhengding (ZD), Luancheng (LC), and Hengshui (HS) sites) were chosen to investigate the groundwater recharge (Figure 1). The ZD and LC sites represent the alluvial plain, and the hydraulic conductivities of the ZD and LC sites were 7.9-274.8 and $100-140 \mathrm{~m} / \mathrm{d}$, respectively, while the HS site represents the lacustrine plain, with hydraulic conductivity of $85-28.5 \mathrm{~m} / \mathrm{d}$.

Irrigation and precipitation were the main sources of recharge through the variable saturated zone. Features of the groundwater level, the texture of the unsaturated zone and land use were different at these sites, shown in Table 1. Additionally, the first aquifer of the HS was salt water with a salinity of $8.9 \mathrm{~g} / \mathrm{L}$.

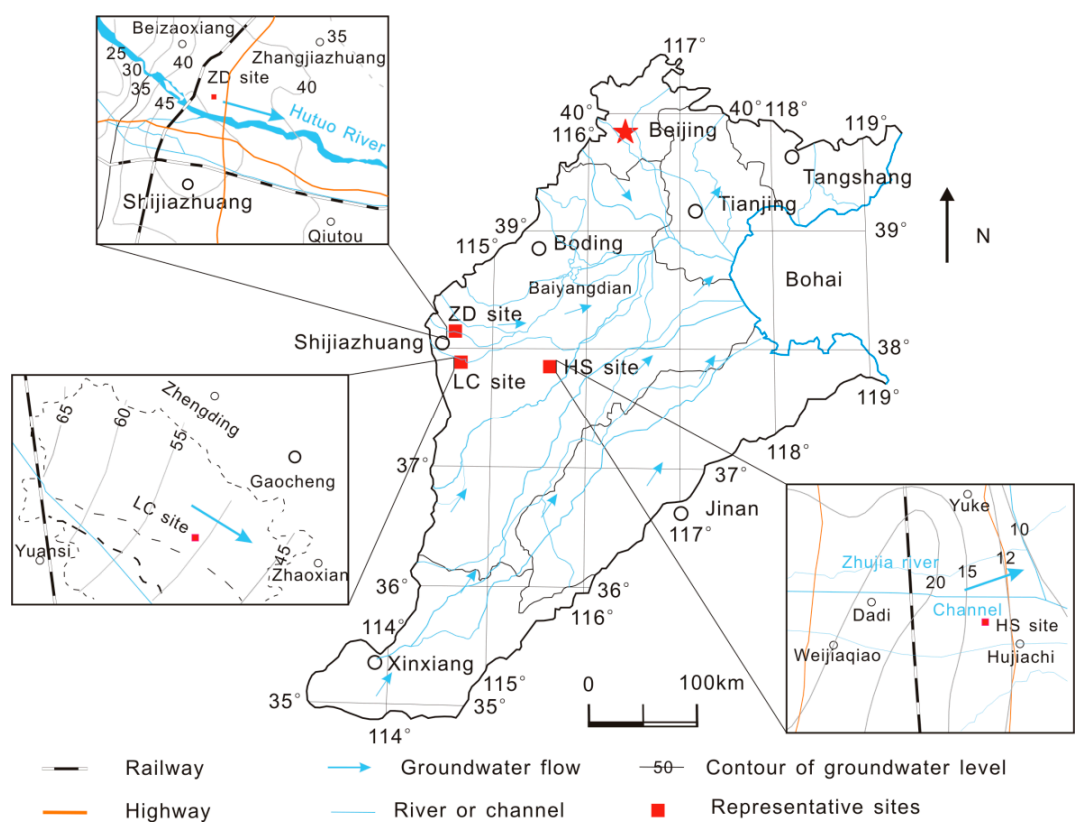

Figure 1. Representative sites of the North China Plain (NCP) in this study: Zhengding (ZD), Luancheng (LC) and Hengshui (HS).

Table 1. General features of the ZD, LC and HS sites.

\begin{tabular}{cccccc}
\hline Site & Lithology & $\begin{array}{c}\text { Groundwater Depth } \\
(\mathbf{m})\end{array}$ & $\begin{array}{c}\text { Precipitation } \\
(\mathbf{m m} / \text { Year })\end{array}$ & $\begin{array}{c}\text { Irrigation } \\
(\mathbf{m m} / \text { Year) }\end{array}$ & $\begin{array}{c}\text { Evaporation } \\
(\mathbf{m m} / \text { Year })\end{array}$ \\
\hline ZD & Clay, silt, sand & 45.0 & 471.8 & 0 & 1655 \\
LC & Clay, silt, sand & 36.5 & 439.5 & 300 & 1528 \\
HS & Clay & 9.0 & 442.6 & 300 & 1148 \\
\hline
\end{tabular}




\section{Materials and Methods}

\subsection{Chloride Mass-Balance Method}

The chloride mass-balance method has been used widely in the world since the 1970s, considered as an effectual and applied method to estimate groundwater recharge [9]. The groundwater recharge was estimated by the mass-balance of chloride. The total chloride deposition (wet and dry) on the surface of soil is equal to the total chloride of soil water or groundwater carried by the groundwater recharge, assuming the chloride is a conservative ion without absorption and exchange with soil and without uptake by plants. The main input sources of chloride on the surface are precipitation, aerosols and irrigation. Then, the groundwater recharge was obtained by Equation (1), according to the principle of mass conservation [11]:

$$
\mathrm{P}_{\text {eff }} \times\left(\mathrm{Cl}_{\mathrm{p}}+\mathrm{Cl}_{\mathrm{s}}\right)=\mathrm{R} \times \mathrm{Cl}_{\mathrm{sw}}
$$

where $\mathrm{P}_{\text {eff }}$ is effective precipitation $(\mathrm{L} / \mathrm{T})$, i.e., the total precipitation deducts the amount of runoff; $\mathrm{Cl}_{\mathrm{p}}$ and $\mathrm{Cl}_{\mathrm{s}}$ are the chloride concentrations of wet (precipitation) and dry deposition, respectively $\left(\mathrm{M} / \mathrm{L}^{3} / \mathrm{T}\right) ; \mathrm{R}$ is the groundwater recharge $(\mathrm{L} / \mathrm{T}) ; \mathrm{Cl}_{\mathrm{sw}}$ is the chloride concentration of soil water below the root zone $\left(\mathrm{M} / \mathrm{L}^{3}\right)$, assuming that the chloride concentration remains constant when the soil water moves below the root zone, while varying in the root zone, attributed to evapotranspiration. If the above assumptions are met, then it could be stated that a higher chloride concentration represents lower groundwater recharge. Commonly, the lateral and vertical recharges are both input sources of groundwater, so the chloride concentration of groundwater described in previous literature should be replaced by the chloride concentration of soil water $\left(\mathrm{Cl}_{\mathrm{sw}}\right)$ in Equation (1).

The mean resident time of soil water can also be calculated according to the profile of chloride concentration. The time represented by chloride concentration at depth $\mathrm{z}$ was evaluated by dividing the total mass of soil water chloride from the surface to the certain depth $\mathrm{d}$ by the annual chloride flux at the soil surface [13]:

$$
\mathrm{t}=\frac{\int_{0}^{\mathrm{d}} \mathrm{Cl}_{\mathrm{sw}} \times \theta \mathrm{dz}}{\mathrm{P}_{\mathrm{eff}} \times\left(\mathrm{Cl}_{\mathrm{p}}+\mathrm{Cl}_{\mathrm{s}}\right)}
$$

\subsection{Applied Tracers Method}

Main applied tracers include bromide, tritium and fluorescent dyes [27]. Considering dyes could be absorbed by soil, conservative tracers, i.e., bromide and tritium, were used to estimate the groundwater recharge in this study. The groundwater recharge is estimated by the following equation, named as the peak method:

$$
\mathrm{R}=\mathrm{v} \times \theta=\frac{\Delta \mathrm{Z}}{\Delta \mathrm{t}} \times \theta
$$

where $\mathrm{R}$ is the recharge rate $(\mathrm{L} / \mathrm{T}) ; \mathrm{v}$ is the vertical percolating velocity of soil water $(\mathrm{L} / \mathrm{T}) ; \Delta \mathrm{Z}$ is the depth of tracer peak (L); $\Delta \mathrm{t}$ is the time between tracer application and sampling $(\mathrm{T})$; and $\theta$ is the average soil volumetric water content within the depth interval $\Delta \mathrm{Z}$ during $\Delta \mathrm{t}$.

In the field, the soil is highly heterogeneous with different pore sizes, especially macropores, where hydraulic conductivity decreases exponentially as soil water content reduces. In other words, the bigger pores will be full of water when soil water content increases, resulting in water transport rapidly along preferential paths and larger groundwater recharge. This was characterized by the dual-porosity model, the dual-permeability model and the multi-porosity and multi-permeability model in previous studies [28-30]. Assuming that bromide and tritium could transport ideally in soil without adsorption, the tracers and soil water have the same flow zone. Therefore, tracer concentration distribution in the soil profile is governed by the multi-porosity (multi-region) flow, a greater depth indicating that tracers moved faster. 
Moreover, the accuracy of the peak method described in the literature was affected by the interval of sampling, i.e., different sampling intervals may result in different recharge. Additionally, the same recharge would be calculated according to the same depth of concentration peak. However, different shapes of the concentration distribution of tracers indicate different recharge in the soil profile with the same depth of concentration peak (Figure 2). The gravity center of the polygon consisting of the concentration profile and depth axis shows larger groundwater recharge with the lower position compared to the surface of the soil. When tracers are applied in the arid zones with the recharge of less than $20 \mathrm{~mm}$ /year, the liquid tracers may lead to large error, commonly $5-10 \mathrm{~mm} /$ year. Therefore, the solid tracers (e.g., solid NaBr) may be more suitable in this area, e.g., the HS site. Additionally, the depth of the tracer's peak in these arid areas may be less than $0.05 \mathrm{~m}$, which is difficult to catch in the field. If the sampling at the interval is more than 0.05 or $0.1 \mathrm{~m}$, recharge is $0 \mathrm{~mm} /$ year estimated by Equation (3), which is not the fact in this area. Therefore, the method needs to improve by the multi-porosity (multi-region) transport model.

The whole flow zone is divided into multi-regions according to pore sizes and the number of regions (n) in this study. Each region has a similar pore size with a similar velocity of soil water. Assuming a smaller number of a region has a higher penetrability, the penetrability of Zone 1 is the largest with the biggest pores, and then the Zone 2 is the second largest with the second biggest pores, and so on; the last zone $n$ owns the smallest pores and the lowest penetrability. The number of regions is decided by the interval distance of the sampling in the profile. The soil profile was also divided into $\mathrm{N}$ regions, and a bigger number has a smaller depth relative to the surface of the soil (Figure 3 ). The recharge could be calculated by Equations (4)-(6) based on the following assumptions:

(1) The travel time of soil water for the whole region is very short, and the total soil water of all sub-regions flows through the tracing face simultaneously.

(2) The total recharge is the summation of each zone, and the area percentage of each zone is equal to the recharge percentage of each zone.

(3) In the profile, the groundwater recharge of each region could be estimated according to Equation (3) multiplying a ratio parameter. The parameter is the tracer's mass percentage of each interval depth in the soil profile. The tracer mass is calculated by each interval depth multiplied by the mean tracer concentration of the interval depth.

(4) The soil water of Zone 1 on the tracing face with the largest flow velocity reaches at Zone 1 of the soil profile with the biggest depth in the soil profile, Zone 2 of the tracing face for Zone 2 of the soil profile, and so on.

$$
\begin{gathered}
\text { On the tracing face: } R=\sum_{i=1}^{N} R_{i}=\sum_{\mathrm{i}=1}^{\mathrm{N}} \frac{S_{i}}{S} R \\
\text { In the profile: } R=\sum_{i=1}^{N} \alpha_{i} \times \overline{\theta_{i}} \times \frac{\Delta \mathrm{Z}_{i}}{\Delta t} \\
\alpha_{\mathrm{i}}=\frac{\Delta \mathrm{z}_{\mathrm{i}} \times \overline{c_{i}}}{\sum_{i=1}^{N} \Delta \mathrm{z}_{\mathrm{i}} \times \overline{c_{i}}}
\end{gathered}
$$

where $\mathrm{R}$ is the total recharge $(\mathrm{L} / \mathrm{T})$; $\mathrm{N}$ is the number of pore zones or the region of the soil profile; $\mathrm{S}_{\mathrm{i}}$ and $S$ are areas of the pore i zone and total zone $\left(\mathrm{L}^{2}\right)$, respectively; $\alpha_{i}$ is the tracer's mass percentage of region $i$ of the soil profile; $\Delta Z_{i}$ and $\Delta z_{i}$ are the transport distant of pore zone $i$ and interval distant of the pore zone $\mathrm{i}(\mathrm{L})$, respectively; $\overline{\mathrm{c}_{\mathrm{i}}}$ is the mean tracer concentration of the region $i$ of the soil profile $\left(\mathrm{M} / \mathrm{L}^{3}\right)$ and $\overline{\theta_{\mathrm{i}}}$ is the mean water content in depth $\Delta \mathrm{Z}_{\mathrm{i}}$.

Additionally, when the recharge rate is especially low, less than $10 \mathrm{~mm} /$ year, it is difficult to investigate the depth of the peak, which is less than $0.05 \mathrm{~m}$ with mean water content of $20 \%$ based on Equation (3). In this case, we could apply solid tracers, such as $\mathrm{NaBr}$ or NaI, the amount of which is 
enough to be dissolved by soil water across the injecting plane, and then, the recharge rate could be calculated by the mass-balance principle and the solubility of tracers as follows:

$$
R=\frac{M_{\mathrm{s}}}{S_{\mathrm{t}}}
$$

where $R$ is the groundwater recharge rate $(\mathrm{L} / \mathrm{T}), M_{S}$ is the total amount of the tracer unit area under the injecting plane $\left(\mathrm{M} / \mathrm{L}^{2}\right)$ and $S_{t}$ is the solubility of the tracer at the mean temperature in the depth of the injecting plane $\left(\mathrm{M} / \mathrm{L}^{3}\right)$.

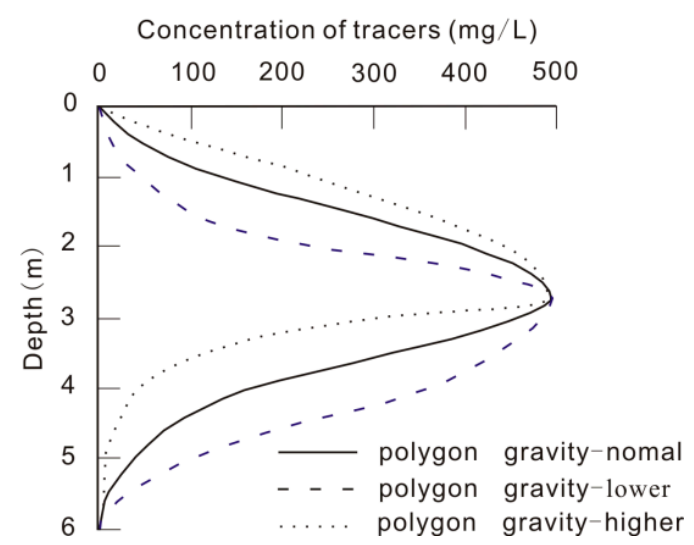

Figure 2. Different distributions of tracers in the soil profile with the same depth of peak.

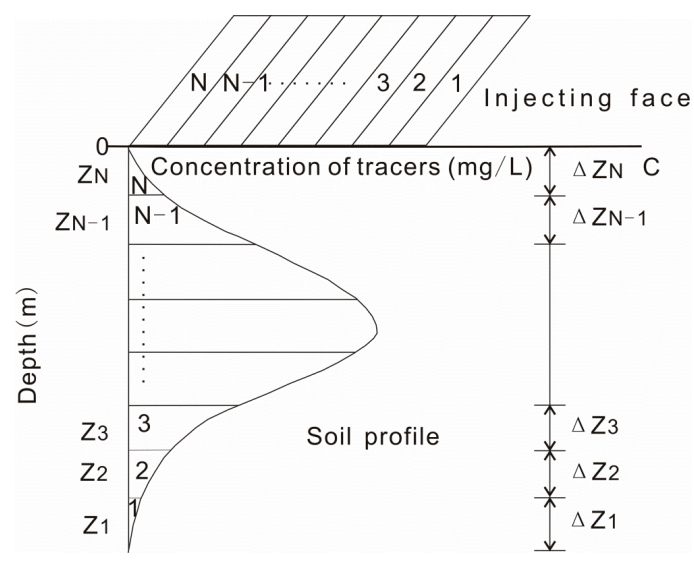

Figure 3. Model of multi-regions for estimating groundwater recharge in this study.

\subsection{Hydrus-1D Modeling Method}

The Hydrus-1D program numerically solves the Richards equation with the finite element method for variable saturated water flow in the soil. The governing equation used in this study is a modified Richard equation, assuming a neglected air phase and thermal gradient as follows [31]:

$$
\frac{\partial \theta}{\partial t}=\frac{\partial}{\partial x}\left[K\left(\frac{\partial h}{\partial x}+1\right)\right]-S
$$

where $\theta$ is the volumetric water content $\left(\mathrm{L}^{3} / \mathrm{L}^{3}\right) ; \mathrm{h}$ is the water pressure head $(\mathrm{L}) ; \mathrm{t}$ is the time $(\mathrm{T}) ; \mathrm{z}$ is the vertical coordinate $(\mathrm{L})$ (positive upward); $\mathrm{K}$ is the unsaturated hydraulic conductivity $(\mathrm{L} / \mathrm{T})$; and $\mathrm{S}$ is the sink term $\left(\mathrm{L}^{3} / \mathrm{L}^{3} / \mathrm{T}\right)$.

At the field scale, the soil surface commonly considered as the upper boundary of the model is so complex that data are uncertain, such as evapotranspiration calculated by the Penman-Monteith equation using meteorological data, soil evaporation and plant transpiration rate. It is difficult to 
measure these parameters exactly in the long term. Moreover, the input time of the precipitation and irrigation on the soil surface is not really one day or the time unit in Hydrus-1D, resulting in the inaccuracy of the input on the surface. Therefore, considering the complexity and uncertainty of the surface condition, we chose the upper boundary under the depth of the root zone (without the sink term, $\mathrm{S}$ is zero). Only the pressure potential and water content were needed to measure in the whole time instead of collecting so much data on the surface. However, long-term data might be needed for a steady upper boundary. Additionally, soil water flows downward all of the time over a depth of $2.2 \mathrm{~m}$ [32], and the depth of the water table is deep enough (the mean value is $36.5 \mathrm{~m}$ for the LC site). Therefore, a free drainage condition for the lower boundary was selected for the model. Boundary and initial conditions could be specified as follows:

$$
\begin{aligned}
& \text { Initial condition: } \mathrm{h}(\mathrm{z}, \mathrm{t})=\mathrm{h}_{\mathrm{i}}(\mathrm{z}) \text { or } \theta(\mathrm{z}, \mathrm{t})=\theta_{\mathrm{i}}(\mathrm{z}) \mathrm{t}=0 \\
& \text { Boundary condition: } \mathrm{h}(\mathrm{z}, \mathrm{t})=\mathrm{h}_{\mathrm{i}}(\mathrm{t}) \mathrm{z}=1.4 \mathrm{~m} \\
& \frac{\partial \mathrm{h}(\mathrm{z}, \mathrm{t})}{\partial \mathrm{x}}=0 \mathrm{z}=3.4 \mathrm{~m}
\end{aligned}
$$

The soil hydraulic properties in this study were described by the following expressions [33]:

$$
\begin{aligned}
& \theta(\mathrm{h})=\left\{\begin{array}{cc}
\theta_{\mathrm{r}}+\frac{\theta_{\mathrm{s}}-\theta_{\mathrm{r}}}{\left[1+|\partial \mathrm{h}|^{\mathrm{n}}\right]^{\mathrm{m}}} & h<0 \\
\theta_{\mathrm{s}} & h \geq 0
\end{array}\right. \\
& \mathrm{K}(\mathrm{h})=\mathrm{K}_{\mathrm{s}} S_{\mathrm{e}}^{\mathrm{l}}\left[1-\left(1-\mathrm{S}_{\mathrm{e}}^{1 / \mathrm{m}}\right)^{\mathrm{m}}\right]^{2}
\end{aligned}
$$

where $\theta_{\mathrm{r}}$ and $\theta_{\mathrm{s}}$ are the residual and saturated water contents $\left(\mathrm{L}^{3} / \mathrm{L}^{3}\right)$, respectively; $\mathrm{K}_{\mathrm{s}}$ is the saturated hydraulic conductivity $(\mathrm{L} / \mathrm{T}) ; 1$ is a pore-connectivity parameter $(-) ; \alpha\left(\mathrm{L}^{-1}\right), \mathrm{m}$ and $\mathrm{n}(\mathrm{m}=1-1 / \mathrm{n})$ are empirical parameters. Additionally, the air-entry value of $-0.2 \mathrm{~m}$ was specified. The single layer of silty clay was considered from $1.4 \mathrm{~m}$ to $3.4 \mathrm{~m}$ in this model.

Model parameters were optimized by the inverse method typically based on the minimization of a suitable objective function, using the effective Levenberg-Marquardt nonlinear minimization method [31]. Five parameters needed to be optimized, which might lead to the uniqueness of the results. The saturated water content and saturated hydraulic conductivity have clear physical significance and can be determined directly [29], and $\theta_{\mathrm{r}}$ and 1 are typically least sensitive to the calibration data [34,35]. The pore-connectivity parameter was estimated to be 0.5 as an average value for many soils [36], and the $\theta_{\mathrm{r}}$ and $\theta_{\mathrm{s}}$ were advised to be 0.099 and 0.365 , respectively [24]. Therefore, the $\alpha, \mathrm{n}$ and $\mathrm{K}_{\mathrm{s}}$ parameters were chosen to be optimized by the inverse method in this model.

\subsection{Experiment Procedure and Data Acquisition}

The experiment was designed to estimate the groundwater recharge of representative areas in the NCP according to different land uses, water levels and depths in 17 sites of ZD, LC and HS. The numbers of the sites were 1, 8 and 8, respectively, shown in Table 2.

It is suitable for the ZD site to estimate groundwater recharge using the chloride mass-balance method, because there have been no human activities for 50 years in the ZD site. Forty-five samples of soil water content and chloride concentration were collected in a soil profile with a depth of $31.5 \mathrm{~m}$ in December 2009, and the interval of sampling is $0.5 \mathrm{~m}$. Soil water was sampled by cutting rings $(\varnothing 7.0 \times 5.2 \mathrm{~cm})$, then dried at $105^{\circ} \mathrm{C}$ for $24 \mathrm{~h}$ until the weight of the soil samples did not vary. The soil samples for chloride analysis were air-dried for 10 days, triturated and filtered by a 1-mm sieve. Then, a 50-g sample was added into $250 \mathrm{~mL}$ of deionized water and shaken for $2 \mathrm{~h}$, then centrifuged at $5000 \mathrm{r} / \mathrm{min}$ for $5 \mathrm{~min}$. The supernate for chloride analysis was measured by the titration method. Additionally, the source of the chloride, including the dry and wet deposit, was monitored by collection equipment beginning in April 2011, which was a stainless steel collector $(\varnothing 20 \times 40 \mathrm{~cm})$ of $1.5 \mathrm{~m}$ height in the ZD site. 
Table 2. Estimation methods of representative areas in NCP.

\begin{tabular}{|c|c|c|c|c|c|}
\hline Number & Lithology & Land Use & Method & Time & Irrigation \\
\hline ZD01 & clay, silt and sand & no human activities & chloride mass-balance & 105 years ago-10 October 2009 & no \\
\hline LC01 & clay, silt & $\begin{array}{l}\text { wheat, corn with straw mulch } \\
\text { wheat and corn } \\
\text { wheat, corn with straw mulch }\end{array}$ & $\begin{array}{c}\mathrm{Br}^{-} \text {and }{ }^{3} \mathrm{H}^{[16]}, \text { modeling } \\
\text { modeling } \\
\mathrm{Br}^{-},{ }^{3} \mathrm{H}\end{array}$ & $\begin{array}{c}5 \text { March 2003-23 September } 2005 \\
24 \text { September 2005-27 September } 2007 \\
\text { 14 December 2009-16 April } 2011\end{array}$ & flood \\
\hline LC02 & clay, silt & wheat and corn & $\mathrm{Br}^{-},{ }^{3} \mathrm{H}$ & 14 December 2009-16 April 2011 & flood \\
\hline LC03 & clay, silt & wheat and corn & $\mathrm{Br}^{-},{ }^{3} \mathrm{H}$ & 14 December 2009-16 April 2011 & flood \\
\hline LC04 & clay, silt & wheat and corn & $\mathrm{Br}^{-},{ }^{3} \mathrm{H}$ & 14 December 2009-16 April 2011 & flood \\
\hline LC05 & clay, silt & no human activities & $\mathrm{Br}^{-}$ & 14 December 2009-16 April 2011 & no \\
\hline LC06 & clay, silt & no human activities & $\mathrm{Br}^{-}$ & 14 December 2009-16 April 2011 & no \\
\hline LC07 & clay, silt & no human activities & $\mathrm{Br}^{-}$ & 14 December 2009-16 April 2011 & no \\
\hline LC08 & clay, silt & grass & $\mathrm{Br}^{-},{ }^{3} \mathrm{H}$ & 14 December 2009-16 April 2011 & no \\
\hline HS01 & clay & wheat and corn & $\mathrm{Br}^{-},{ }^{3} \mathrm{H}$ & 20 December 2009-20 April 2011 & furrow \\
\hline HSO2 & clay & wheat, corn with straw mulch & $\mathrm{Br}^{-},{ }^{3} \mathrm{H}$ & 20 December 2009-20 April 2011 & flood \\
\hline HS03 & clay & no human activities & $\mathrm{Br}^{-}$ & 20 December 2009-20 April 2011 & no \\
\hline HSO4 & clay & no human activities & $\mathrm{Br}^{-}$ & 20 December 2009-20 April 2011 & no \\
\hline HS05 & clay & no human activities & $\mathrm{Br}^{-}$ & 20 December 2009-20 April 2011 & no \\
\hline HS06 & clay & no human activities & $\mathrm{Br}^{-}$ & 20 December 2009-20 April 2011 & no \\
\hline HS07 & clay & no human activities & $\mathrm{Br}^{-}$ & 20 December 2009-20 April 2011 & no \\
\hline HS08 & clay & wheat and corn & $\mathrm{Br}^{-}$ & 20 December 2009-20 April 2011 & sprinkling \\
\hline
\end{tabular}


Some sites were chosen to estimate groundwater recharge under different land uses, for example wheat and corn, wheat and corn with straw mulch, grass without irrigation, no human activities and different types of irrigation (e.g., furrow irrigation, flood irrigation and sprinkling irrigation) in the LC and HS sites. Firstly, the LC01 site, where the winter wheat and summer corn were planted during the experiment, was set up to monitor the soil water movement $(3.4 \mathrm{~m}$ ) by the neutron probe (IH-II probe, Didcot Instrument Co., Cambridge, UK) and the MW-1 tensiometer system designed by the Institute of Hydrogeology and Environment Engineer, CAGS (Chinese Academy of Geological Sciences), from 5 April 2003 to 27 September 2007. From the soil surface to a depth of $3.4 \mathrm{~m}, 20$ monitored sites were designed to measure soil water content and potential simultaneously. The interval of depth for the monitored sites was $0.1 \mathrm{~m}$ in the first $1.0 \mathrm{~m}$ and $0.2 \mathrm{~m}$ for more than a $1.0-\mathrm{m}$ depth. After rainfall or irrigation, we collected the data at $0.5,1.0,1.5,2.0,2.5,3.0,4.0,5.0$ and $6.0 \mathrm{~h}$, then twice in the following two days, once in the next 3 days and 3 days a time until it rained or it was irrigated again. Straw mulch, which was made of summer corn with a length of $0.2-0.5 \mathrm{~m}$ and a density of $0.6 \mathrm{~kg} / \mathrm{m}^{2}$, was covered on the soil surface from 4 December 2003 to 19 October 2005. Bromide and tritium tracer tests were conducted from 11 March 2003 to 23 September 2005 (at $1.0 \mathrm{~m}$ depth) and 14 December 2009 to 16 April 2011 (at a $2.0 \mathrm{~m}$ depth), respectively. The concentrations of tritium were 1 billion and 2 million Tritium Units for the two periods, respectively. The amounts of bromide and tritium were $200 \mathrm{~g}$ and $30 \mathrm{~mL}$, respectively, for each monitoring point, if they were applied. The other experiment sites, such as LC02 $\left(\mathrm{Br}^{-}\right.$and $\left.{ }^{3} \mathrm{H}\right)$ with wheat and crop, LC05 $\left(\mathrm{Br}^{-}\right)$without human activities, $\mathrm{LC} 08\left(\mathrm{Br}^{-}\right.$and $\left.{ }^{3} \mathrm{H}\right)$ with grass and no irrigation, $\mathrm{HSO}\left(\mathrm{Br}^{-}\right.$and $\left.{ }^{3} \mathrm{H}\right)$ with furrow irrigation, $\mathrm{HSO} 2\left(\mathrm{Br}^{-}\right.$and $\left.{ }^{3} \mathrm{H}\right)$ with straw mulch and flood irrigation, HSO3 $\left(\mathrm{Br}^{-}\right.$and $\left.{ }^{3} \mathrm{H}\right)$ without human activities for 30 years and HS08 $\left(\mathrm{Br}^{-}\right)$ with sprinkling irrigation, were conducted simultaneously and shown in Table 2.

Tracing tests at different depths were conducted in the LC and HS sites. In the LC02, LC03 and LC04 sites, where wheat and corn were planted, bromide and tritium tracers were injected at $2.0 \mathrm{~m}$, $3.0 \mathrm{~m}$ and $4.0 \mathrm{~m}$ depths, respectively. Additionally, in the LC05, LC06 and LC07 sites without human activities, only the bromide tracer was injected at $2.0 \mathrm{~m}, 3.0 \mathrm{~m}$ and $4.0 \mathrm{~m}$ depths, respectively. In the HS03, HS04, HS05, HSO6 and HS07 sites without human activities, the bromide tracer was applied at $2.0 \mathrm{~m}, 2.5 \mathrm{~m}, 3.0 \mathrm{~m}, 3.5 \mathrm{~m}$ and $4.0-\mathrm{m}$ depths, respectively.

The soil sampling depth intervals were $0.1 \mathrm{~m}$ from $0.0 \mathrm{~m}$ to $0.8 \mathrm{~m}$ (relatively the depth of injected tracers), then $0.2 \mathrm{~m}$ below a $0.8 \mathrm{~m}$ depth for the measurement of soil water content and the concentrations of bromide and tritium. Each sample of $100 \mathrm{~g}$ for soil water was collected in an aluminum box, measured by the dried method. Each tritium sample of $200 \mathrm{~g}$ was packed by preservative film and stored immediately in an icebox to prevent the water from evaporating, then the soil water was extracted by special equipment (designed by China University of Geosciences, Wuhan, China) and measured by a liquid scintillation analyzer in Wuhan. Lastly, bromide samples were pre-processed as the chloride, measured by an ion electrode method (Model: PBr-1, 217, made by Shanghai Precision \& Scientific Instrument Co., Ltd., Shangai, China).

\section{Results and Discussion}

\subsection{Chloride Profile}

The chloride deposition rate controlled by the climatic conditions [36] was constant in the ZD site far away from the ocean. In the ZD site, human effects and additional contributions of $\mathrm{Cl}^{-}$were not existent, and then, variable evaporation resulted in several peaks in the soil profile (Figure 4). The oscillations of chloride indicated that the groundwater recharge was not constant in the long term (Figure 5). The mean chloride concentration was $574.1 \mathrm{mg} / \mathrm{L}$, ranging from $1508.3 \mathrm{mg} / \mathrm{L}$ (at $12.7 \mathrm{~m}$ ) to $67.0 \mathrm{mg} / \mathrm{L}$ (at $28.5 \mathrm{~m}$ ). The mean annual chloride deposition including wet and dry was $22.1 \mathrm{~g} / \mathrm{m}^{2} /$ year, much more than the mean chloride of rainfall $3.63 \mathrm{~g} / \mathrm{m}^{2} /$ year [37], showing that the dry deposition was vital, especially in this area with a high value of bug dust. According to Equation (1), the groundwater recharge was only $0.7 \%$ and annual precipitation of $533.34 \mathrm{~mm} /$ year with the mean 
value of $3.84 \mathrm{~mm} /$ year, which resulted from the interbed structure of the soil profile with clay and medium coarse sand. The surface of the soil has been covered by the air-dried artificial and densified soil of a $1.1 \mathrm{~m}$ depth, where it was difficult for rainfall to infiltrate.

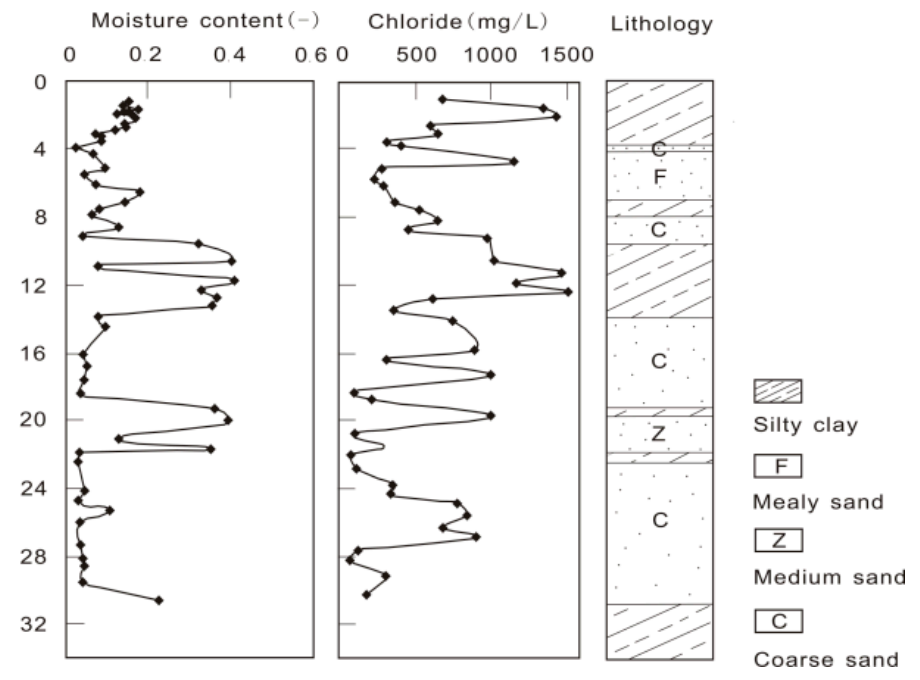

Figure 4. $\mathrm{Cl}^{-}$concentration, soil moisture content and lithology profiles at the ZD site.
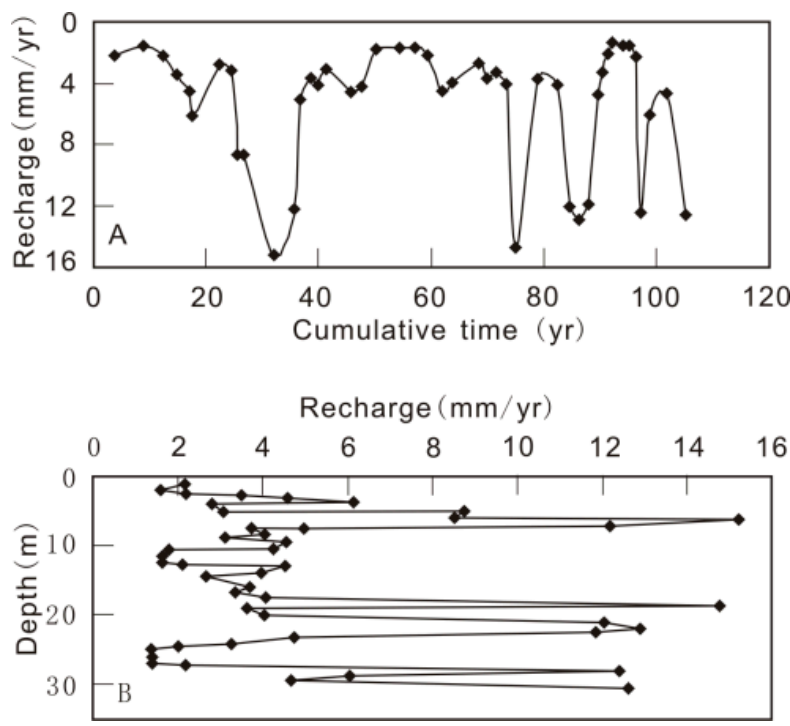

Figure 5. Groundwater recharge at the ZD site.

\subsection{Applied Tracers Profile}

Applying tracers on the soil surface or in the rooting zone, where preferential flow dominated mainly, soil water flow fluctuated up and down above the maximal depth of evaporation, might lead to uncertain results of recharge estimation. It was noted that we could inject tracers into the depth between the rooting zone and the maximal depth of evaporation, but the period of the tracer test must be a whole year or integer years, otherwise the value obtained by Equation (3) was not the real groundwater recharge. Therefore, bromide and tritium tracers were applied in the LC and HS sites at a depth of $2.0 \mathrm{~m}$ in the soil, above where the percentages of plant roots were $99 \%$ and $100 \%$ for winter wheat and summer corn, respectively $[38,39]$. Additionally, the soil water moved downwards, always over the depth of $2.0 \mathrm{~m}$ in the LC site [32].

The results of the applied tracers showed that the annual groundwater recharges ranged from 64.0 to $167.5 \mathrm{~mm}$ /year and 16.1 to $20.1 \mathrm{~mm}$ /year, and the mean values were 124.3 and $18.0 \mathrm{~mm}$ /year, 
in the LC and HS site, respectively, shown in Table 3 and Figure 6. The results of recharge by the peak method were lower than the multi-region method and mass balance, which was attributed to that multi-region method considering soil heterogeneity and preferential flow rather than uniform flow or piston flow, which matched better the fact in the field. In the HS site, the recharge rates of the peak method were all zero, which was unsuitable. The mass-balance method was a reliable method only suitable for no peak of the tracer, alternatively, without considering the complicated soil structure, which matched well with the result of the multi-region method. Therefore, this study was advised to estimate groundwater recharge by the multi-regions and mass balance method. Results of bromide and tritium were the same by the peak method to estimate recharge, while there were different results by the multi-region model. The main reason might be that the transfer behavior of bromide rather than tritium in soil was effected by the soil charge, i.e., when the total charge is positive with more cations, the soil would absorb anions [40,41], e.g., bromide ions, resulting in a smaller recharge rate, such as in the LC01, LC02 and LC08. Additionally, when the total charge is negative with more anions, the effect of ion exclusion would happen [16,42], resulting in a larger recharge rate, such as in LC03, LC04, HS01, $\mathrm{HSO2}$ and HS03. However, the differences of the annual groundwater recharge between the results of the bromide and tritium by the multi-region method were $14.3 \%$ and $2.9 \%$ in the LC and HS sites, respectively, which could be explained by the higher recharge rate for the LC site of $124.3 \mathrm{~mm} /$ year, leading to a larger difference of transfer for two tracers.

Table 3. Results of groundwater recharge by applied tracer methods, mm/year.

\begin{tabular}{|c|c|c|c|c|c|c|}
\hline \multirow{2}{*}{ Number } & \multirow{2}{*}{ Tracer } & \multicolumn{4}{|c|}{ Recharge } & \multirow{2}{*}{ Injecting Depth (m) } \\
\hline & & Multi-Region & Peak & Mass Balance & Mean * & \\
\hline \multirow{2}{*}{ LC01 } & Bromide & 149.5 & 160.8 & - & 149.5 & \multirow{2}{*}{2.0} \\
\hline & Tritium & 167.5 & 160.8 & - & 167.5 & \\
\hline \multirow{2}{*}{ LC02 } & Bromide & 154.2 & 141.0 & - & 154.2 & \multirow[b]{2}{*}{2.0} \\
\hline & Tritium & 159.4 & 141.0 & - & 159.4 & \\
\hline \multirow{2}{*}{ LC03 } & Bromide & 142.6 & 110.4 & - & 142.6 & \multirow{2}{*}{3.0} \\
\hline & Tritium & 127.8 & 110.4 & - & 127.8 & \\
\hline \multirow{2}{*}{ LC04 } & Bromide & 147.8 & 135.0 & - & 147.8 & \multirow{2}{*}{4.0} \\
\hline & Tritium & 129.9 & 135.0 & - & 129.9 & \\
\hline LC05 & Bromide & 96.0 & 68.5 & - & 96.0 & 2.0 \\
\hline LC06 & Bromide & 76.6 & 54.8 & - & 76.6 & 3.0 \\
\hline LC07 & Bromide & 64.0 & 0.0 & - & 64.0 & 4.0 \\
\hline \multirow{2}{*}{ LC08 } & Bromide & 83.6 & 62.7 & - & 83.6 & 2.0 \\
\hline & Tritium & 116.8 & 62.7 & - & 116.8 & 2.0 \\
\hline \multirow{2}{*}{ HS01 } & Bromide & 18.3 & 0.0 & 17.8 & 18.05 & \multirow[b]{2}{*}{2.0} \\
\hline & Tritium & 17.6 & 0.0 & - & 17.6 & \\
\hline \multirow{2}{*}{ HSO2 } & Bromide & 17.5 & 0.0 & 17.3 & 17.4 & \multirow{2}{*}{2.0} \\
\hline & Tritium & 17.2 & 0.0 & - & 17.2 & \\
\hline \multirow{2}{*}{ HS03 } & Bromide & 16.6 & 0.0 & 16.3 & 16.45 & \multirow{2}{*}{2.0} \\
\hline & Tritium & 16.1 & 0.0 & - & 16.1 & \\
\hline HS04 & Bromide & 20.5 & 0.0 & 19.7 & 20.1 & 2.5 \\
\hline HS05 & Bromide & 18.9 & 0.0 & 18.7 & 18.8 & 3.0 \\
\hline HS06 & Bromide & 18.5 & 0.0 & 18.1 & 18.3 & 3.5 \\
\hline HSO7 & Bromide & 19.9 & 0.0 & 19.5 & 19.7 & 4.0 \\
\hline HS08 & Bromide & 19.2 & 0.0 & 17.4 & 18.3 & 2.0 \\
\hline
\end{tabular}

Note: * The mean values were calculated without the results of the peak method. 

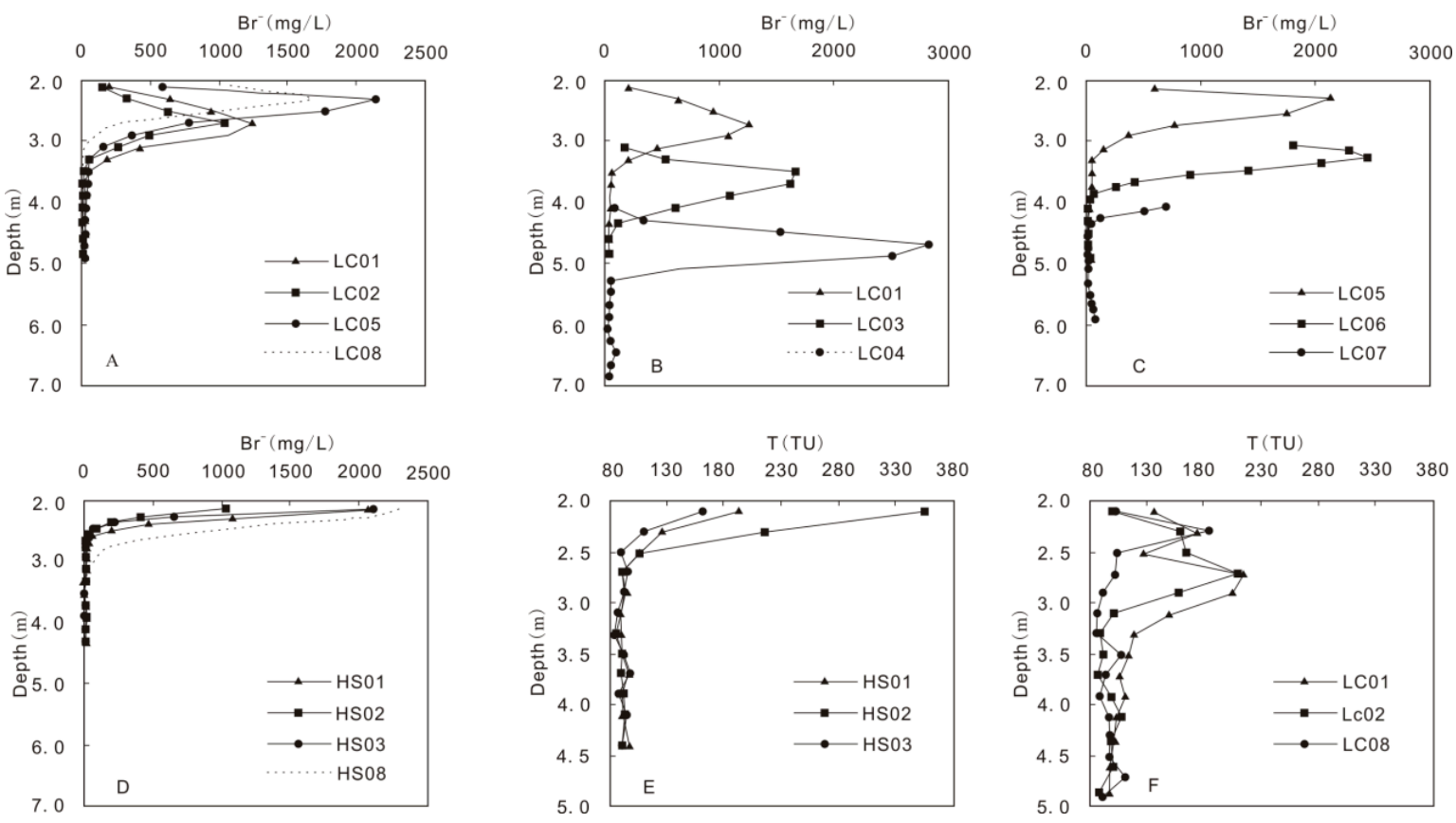

Figure 6. Tracers' concentration profiles in the LC and HS sites: (A) different land utilization in the LC site $\left(\mathrm{Br}^{-}\right)$; (B) different injected depths of the tracers $\left(\mathrm{Br}^{-}\right)$in the LC site; $(\mathbf{C})$ different injected depths of the tracers $\left(\mathrm{Br}^{-}\right)$without human activities in the LC site; (D) different land utilization in the HS site $\left(\mathrm{Br}^{-}\right)$; (E) different land utilization in the HS site (T); (F) different land utilization in the LC site (T).

Although compared to the peak method, the method of multi-regions showed some advantages in estimating groundwater recharge by the applied tracers, this method was firstly applied to estimate groundwater recharge. Therefore, these results of the multi-region method should be checked by other standard methods (e.g., a larger scale lysimeter) for recharge estimation in future studies. Additionally, the results were also influenced by the sampling interval, i.e., more reasonable results for a smaller sampling interval.

\subsection{Hydrus-1D}

Considering the complexity and uncertainty of data on the surface of soil, the depth of $1.4 \mathrm{~m}$ was chosen as the upper boundary of the Hydrus-1D model instead of the soil surface, where the plant roots almost did not exist, illustrating that the sink term of the roots could be ignored, and soil water flow was more stable than the soil surface. Moreover, the irrigation and rainfall data were input in days if the soil surface was chosen as the upper boundary of the model. However, the continuing time of irrigation and rainfall was not always in days exactly in the field.

The sensitivities of the soil water content, soil potential and recharge to $\alpha, n$ and $\mathrm{K}_{\mathrm{s}}$ were high, while low sensitivities to the parameters $\theta_{\mathrm{r}}, \theta_{\mathrm{s}}$ and 1 , and the higher sensitivity showed a higher chance to identify the parameters for the inverse method [2,35]. The optimization algorithm was effective when the number of parameters needed to be identified was less than four $[43,44]$. Therefore, the parameters $\alpha, n$ and $K_{s}$ were chosen to optimize by the inverse code of Hydrus-1D, and the parameters $\theta_{\mathrm{r}}, \theta_{\mathrm{s}}$ and 1 were fixed with the values of $0.09,0.365$ and 0.5 , respectively. The initial values of $\alpha, \mathrm{n}$ and $\mathrm{K}_{\mathrm{s}}$ were assigned to $0.0151,1.5$ and 1.6, respectively. Ten observation nodes were designed at a depth of 1.4 m-3.4 m from April 2003 to October 2007, where the data of soil water content and potential were measured and were used in the inverse model. According to the results of inverse modeling, shown in Table 4, the values of $\alpha, \mathrm{n}$ and $\mathrm{K}_{\mathrm{s}}$ were $0.1029,1.279$ and 36.61, respectively, with the correlation coefficient $r^{2}$ of 0.8035 . The results also showed that the modeled soil water content did not match well for a short time ranging from April 2003 to August 2003, suggesting that a long-term 
experiment could provide more information for the parameter optimization [45]. A close fit had been shown between measured and simulated soil water content at different depths in the soil profile in Figure 7. However, the modeled curves did not match the peaks of the measured cures, and the peaks appeared almost during rainy seasons; the main reason might be that preferential flow would happen when the amount of rainfall (including irrigation) was large [46], and the preferential flow was not considered in this model.

Table 4. Result of the hydraulic parameter estimation by the inverse method.

\begin{tabular}{ccccccc}
\hline Parameter & $\theta_{\mathbf{r}}\left(\mathbf{c m}^{\mathbf{3}} / \mathbf{c m}^{3}\right)$ & $\theta_{\mathbf{s}}\left(\mathbf{c m}^{3} / \mathbf{c m}^{3}\right)$ & $\alpha\left(\mathbf{c m}^{-1}\right)$ & $\mathbf{n}(-)$ & $\mathbf{K}_{\mathbf{s}}(\mathbf{c m} / \mathbf{d})$ & $\mathbf{L}(\mathbf{c m} / \mathbf{c m})$ \\
\hline Initial estimate & 0.09 & 0.365 & 0.0151 & 1.5 & 1.6 & 0.5 \\
Minimum value & - & - & 0.01 & 1.1 & 0.2 & - \\
Maximum value & - & - & 1 & 3.0 & 60.0 & - \\
Optimized value & 0.09 & 0.365 & 0.1029 & 1.279 & 36.61 & 0.5 \\
\hline
\end{tabular}

(A)

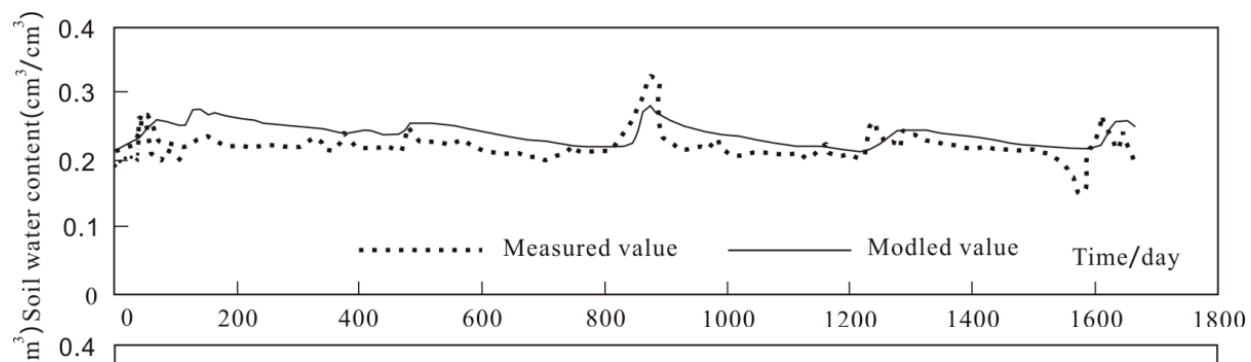

(B)

(C)

(D)

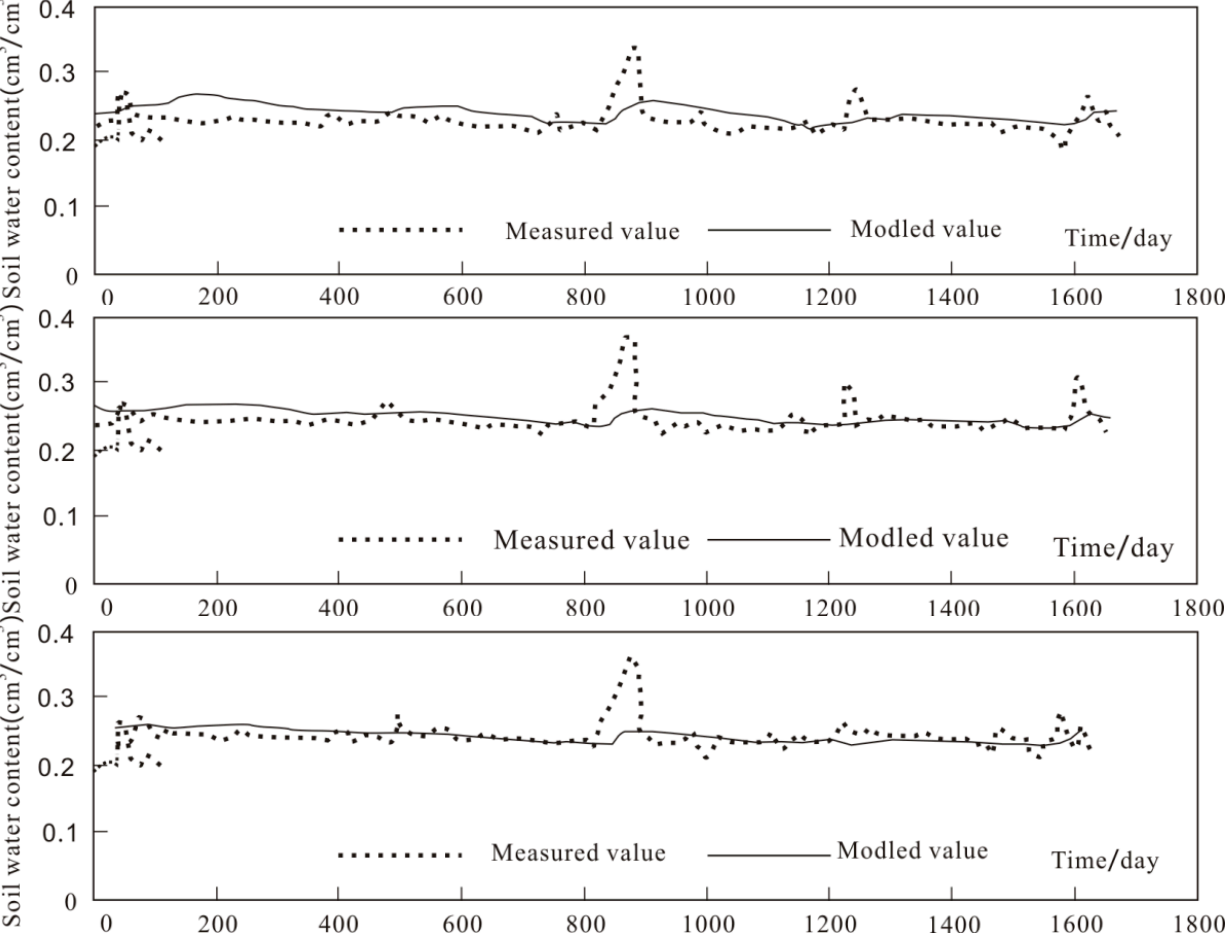

Figure 7. Comparison between measured and modeled soil water content values of different depths in the soil profile in the LC site at different depths of the soil profile: (A) $1.8 \mathrm{~m}$; (B) $2.0 \mathrm{~m}$; (C) $2.2 \mathrm{~m}$; (D) $2.4 \mathrm{~m}$.

Figure 8 shows that the precipitation, irrigation, evapotranspiration and flow flux at the bottom boundary $(3.4 \mathrm{~m})$ changed daily. The flow flux of the bottom was always a positive value, which suggested that the soil water at $3.4 \mathrm{~m}$ flowed downward to the groundwater during the whole experiment, i.e., the flux at $3.4 \mathrm{~m}$ was considered as groundwater recharge. 


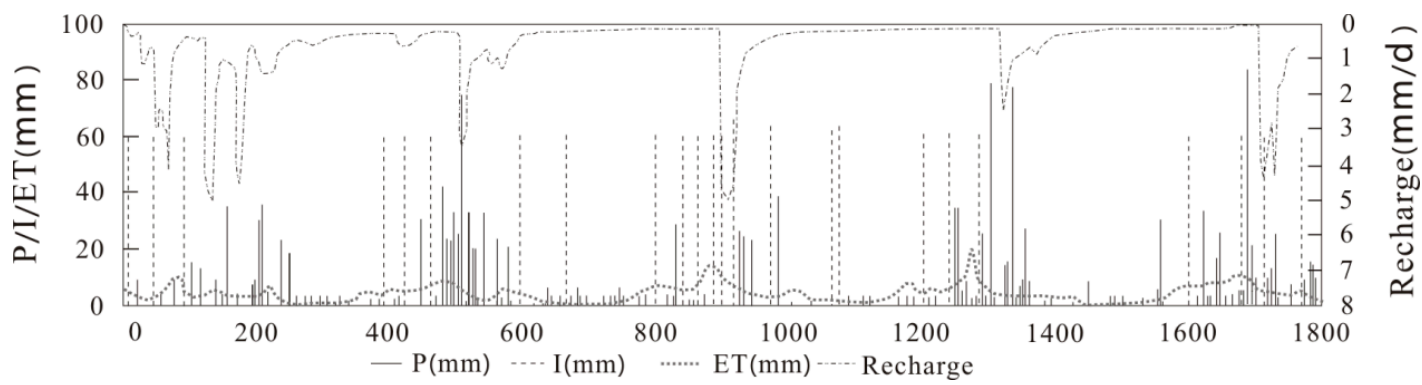

Figure 8. Recharge, precipitation, irrigation and evaporation varied with time, from 4 April 2003 to 27 September 2007 at the LC site.

In general, in dry periods (October-April of the next year), the groundwater recharge was smaller, and kept stable, while groundwater recharge increased quickly when rainfall or irrigation happened on the soil surface, then reduced gradually after rainfall seasons. It is worth noting that it would cost some days (called the retardation time) for rainfall or irrigation arriving at the depth of $3.4 \mathrm{~m}$. However, the retardation time of 2003 was 20-60 days, less than the average value of 130 days for 2004-2007, resulting from the total amount of rainfall of $2003(581 \mathrm{~mm})$ being greater than other years (535, 413, 469 and $426 \mathrm{~mm}$ for 2004, 2005, 2006 and 2007, respectively). In addition, according to the results of the tracing test in the LC site in 2004 [16], the peaks of tracers varied from 0.5 to $0.7 \mathrm{~m}$, and the influence ranges were about 2.0-2.5 m, illustrating that there was a retardation of 250-365 days for most of the soil water moving to the depth of $3.4 \mathrm{~m}$ from the upper boundary.

The mean of recharge rate in the LC site was $225 \mathrm{~mm} /$ year, shown in Table 5, and the mean groundwater recharge was $230 \mathrm{~mm} /$ year during 2003 and 2004, which matched well the result of the tracer test with $215 \mathrm{~mm} /$ year [16]. The recharge rates were influenced by the sum of rainfall and irrigation, land use, water table, soil texture and structure.

Table 5. Recharge rate of LC site from 2003 to 2007 at the LC site.

\begin{tabular}{cccccc}
\hline Time & $\mathbf{2 0 0 3}$ & $\mathbf{2 0 0 4}$ & $\mathbf{2 0 0 5}$ & $\mathbf{2 0 0 6}$ & $\mathbf{2 0 0 7}$ \\
\hline Recharge rate (mm/year) & 340 & 230 & 230 & 106 & 90 \\
Recharge coefficient (\%) & 42.3 & 27.3 & 26.6 & 15.3 & 13.4 \\
\hline
\end{tabular}

In conclusion, the results of the model were reasonable, and the model method would be suggested to evaluate the recharge if the soil water content or soil matric potential, irrigation and meteorological condition could be monitored in the long term.

\subsection{Land Use and Irrigation Types}

Four types of land use (e.g., winter wheat and summer corn, winter wheat and summer corn with straw mulch, grass without irrigation and no human activities) were studied in the LC site from December 2009 to April 2011, shown in Figure 6A. The highest recharge of $158.5 \mathrm{~mm} /$ year was in the LC01 site covered by straw mulch. The next highest recharge was $156.8 \mathrm{~mm} /$ year in the LC02 site planted with winter wheat and summer corn, which indicated that straw mulch could slightly improve recharge, which is consistent with the previous study [32]. Recharge of $96.0 \mathrm{~mm} /$ year in the LC05 site without human activities was lower than in the LC08 site covered by grass without irrigation. One reason might be that grass could hold more rain in the soil and much more rain runoff from the soil surface in the LC05 site during heavy rain. The results showed that human activities could increase groundwater recharge by $59.6 \%$ in the LC site.

In the HS site, the sequence of groundwater recharge values from high to low was the HS08 site (wheat and corn sprinkling irrigation), HS01 (wheat and corn furrow irrigation), HSO2 (wheat and corn flood irrigation) and HS03 (no irrigation and no plants), shown in Figure 6D,E. More than $30 \mathrm{~mm}$ 
of irrigation during the experiment might make the highest recharge in the HS08 site. However, the differences between sites with various land-use were smaller than in the LC site, intimating that the structure of the soil with low permeability played a controlling role in the movement of soil water, rather than the human activities as irrigation (including flood and sprinkling irrigation) and land utilization in the HS site.

\subsection{Different Depth}

Tracing experiments were designed to study the velocity of water flow at different depths of the soil profile, which could answer directly how soil water transferred in the whole soil profile during the same period and how much water moved down to groundwater under the maximum depth of evaporation. The result of this study showed that the recharge rate decreased with the larger depth in the no human activity sites (LC05, LC06 and LC07) (Figure 6C); however, the relationship of recharge rate and depth was not clear in the human activity sites, which accounted for irrigation and plants. However, the results in the HS site were different, indicating that recharge might be controlled by the low permeability layer of clay.

\subsection{Precipitation and Irrigation}

Precipitation and irrigation were the main sources of groundwater recharge, influencing the groundwater recharge. In the LC site, a positive relation between the annual recharge and the sum of precipitation and irrigation was good (Equation (14)) and matched the previous literature [16], except for the recharge of 2003.

$$
\mathrm{R}=1.289(\mathrm{P}+\mathrm{I})+557.02, \mathrm{r}^{2}=0.99
$$

where $\mathrm{R}$ is the annual groundwater recharge (L); P and I is the annual precipitation and irrigation (L), respectively; $\mathrm{r}^{2}$ is the correlation coefficient. The main reason why the groundwater recharge (larger than 2004-2007) did not agree with the Equation (14) was the several heavy rainfalls and irrigations during 2003, i.e., the sums of rainfall and irrigation from 13 May 2003 to 14 May 2003, from 25 July 2003 to 1 August 2003, from 10 October 2003 to 12 October 2003 were $105.8 \mathrm{~mm}, 194.0 \mathrm{~mm}$ and $84.1 \mathrm{~mm}$, respectively. In the field, irrigation was decided by the soil water content for plants. Generally, higher soil water needs less or no irrigation in the rooting zone, which makes soil water move faster, resulting in a higher recharge rate in different periods of the same site (LC). However, in those special cases, the sum of irrigation and rainfall was much higher than the amount of soil water taken up by plant roots, resulting in that most of the rainfall infiltrated into the groundwater aquifer. Therefore, the annual groundwater recharge of 2003 was $110 \mathrm{~mm}$ more than 2004 and 2005, although the sum of irrigation and rainfall of 2003 was 40 and $60 \mathrm{~mm}$ less than 2004 and 2005, respectively. The mean annual coefficients of groundwater recharge defined by the ratio of annual recharge to total precipitation (including irrigation) at the ZD, LC and HS sites were $0.82 \%, 15.4 \%$ and $4.07 \%$, respectively, according to the results of the tracer and chloride methods.

\subsection{Temporal and Spatial Changes of Recharge}

In the temporal scale, groundwater recharge was controlled by precipitation, irrigation, evapotranspiration, soil hydraulic properties and the water table. In the ZD site, a long-term serial recharge rates could be calculated by Equation (1), according to the data of chloride concentration in the whole soil profile of a 31.6- $\mathrm{m}$ depth, with the annual recharge of $3.84 \mathrm{~mm} /$ year. The resident time of soil water at the depth of $31.6 \mathrm{~m}$ was about 105 years, according to Equation (2). The recharge varying with time is presented in Figure 5, showing that there were several recharge rates more than $12.0 \mathrm{~mm}$ /year, i.e., 15.2, 14.7, 12.2, 12.4 and $12.6 \mathrm{~mm}$ /year in 32, 75.1, 83-88, 97.3 and 105 years ago, respectively. However, in most of the years, the recharges were low and ranged from 1 to $4 \mathrm{~mm} /$ year.

In the LC site, according to the results of modeling, the temporal characteristic of groundwater recharge was shown in Figure 8. Generally, recharge increased gradually from April to September, then 
decreased rapidly from September-March of the next year, and the maximum and minimum values always appeared in rainy periods (from July to August) and dry periods (from January to March), respectively [32].

The spatial characteristics of groundwater recharge were analyzed with the data of the no human activity sites, i.e., ZD01, LC05, LC08 and HS03. In the spatial scale, a linear relation between groundwater recharge and the sum of precipitation and irrigation with a low correlation coefficient of 0.67 is shown in Equation (15), as follows:

$$
\mathrm{R}=2.031(\mathrm{P}+\mathrm{I})+441.81, \mathrm{r}^{2}=0.67
$$

where $\mathrm{R}$ is groundwater recharge $(\mathrm{L} / \mathrm{T}) ; \mathrm{P}$ and I are precipitation and irrigation $(\mathrm{L} / \mathrm{T})$, respectively; $\mathrm{r}^{2}$ is the correlation coefficient. In other words, the recharge was larger in the piedmont plain (LC site) than the lacustrine plain (HS site), agreeing with the previous study $[16,24]$. The recharge (ZD site) was lowest, resulting from the air-dried artificial and densified soil of $1.1 \mathrm{~m}$ covering the soil surface. Soil hydraulic properties were intrinsic parameters influencing the recharge rate in the field area, while precipitation (including irrigation) played an important external factor. Although the LC05 and ZD sites have similar characteristics, i.e., without human activities, soil lithology (0-3.4 m silt clay), annual precipitation (471.2 and $439.5 \mathrm{~mm}$ for the ZD and LC sites, respectively) and water level (40.0 and $36.5 \mathrm{~m}$ for the ZD and LC sites, respectively), the mean recharge rates of the ZD and LC sites were different, with 3.84 and $96.0 \mathrm{~mm} /$ year, respectively. This was explained by the soil water content in the ZD site (13.7\%) being lower $11.2 \%$ than the LC site, and the soil structure of the ZD site inhibited the infiltration of precipitation from the soil surface.

Although the groundwater depth in the HS site was only $9.0 \mathrm{~m}$, rather smaller than the LC and ZD sites (36.5 and $45.0 \mathrm{~m}$, respectively), the recharge was only $17.1 \mathrm{~mm} /$ year. Additionally, the LC and HS sites had similar conditions of rainfall and plants.

Thus, the lithology of the sites can largely affect the recharge rate in the ZD, LC and HS sites.

\section{Conclusions}

In this study, chloride mass-balance, tracers (bromide and tritium) and the Hydrus-1D modeling methods were used together to estimate the groundwater recharge of the ZD, LC and HS sites in the $\mathrm{CNP}$, and each method was suitable for a certain condition. For the applied tracer, the multi-region and mass balance methods were firstly introduced to estimate groundwater recharge in this study.

The result of the chloride mass-balance method showed that the mean recharge rate was $3.84 \mathrm{~mm} /$ year, while the mean annual groundwater recharges of the LC and HS sites estimated by the multi-region and mass balance methods of the applied tracer were 124.3 and $18.0 \mathrm{~mm} /$ year, respectively. Groundwater recharges calculated by the multi-region method were more reasonable results than the peak method, especially for no peak appearing in the tracer's concentration profile. Furthermore, the peak method could not be suitable for areas with less than $20 \mathrm{~mm} /$ year of recharge, as no peak appeared or the depth of the peak was so small that it is difficult to identify at the interval of more than $0.1 \mathrm{~m}$ in the field at present. Additionally, the mass balance method matching with the multi-method was an alternative method to estimate groundwater recharge in the field.

The result of modeling matched well the measured values of soil water content and the result of the applied tracer, which showed that choosing the depth of $1.4 \mathrm{~m}$ where most plant roots could not reach as the upper boundary of Hydrus-1D could solve effectively the complexity condition on the soil surface.

Human activities, such as straw mulch and irrigation types, improved groundwater recharge, and the recharge rate increased with a larger depth in the LC site generally, but different in the HS site. The positive linear relation of recharge and the sum of irrigation and rainfall was shown in the spatial scale in the ZD, LC and HS sites and in the temporal scale in the LC site. 
In future studies, some questions need to be solved for understanding the mechanism of soil water transfer and the variation of recharge: firstly, how to attain the exact soil structure and to evaluate the role of soil structure on the recharge. The characteristic of soil pores, especially for preferential paths, could control mainly the groundwater recharge. Secondly, it is necessary to improve the methods of estimating groundwater recharge. Multiple methods may provide reasonable values. Some applied tracers, e.g., fluorescent, could be also considered to estimate groundwater recharge. The applicable conditions for each estimated method are different; therefore, how to choose appropriate methods to evaluate recharge is vital. Thirdly, the results of the multi-region and mass balance methods should be checked by other standard methods (e.g., larger scale lysimeter) for recharge estimation in future studies, and a smaller sampling interval should be designed to improve the precision of the results. Additionally, long-term data should be monitored for model optimization.

Acknowledgments: This study was supported by the National Basic Research Program of China973 Program (2010CB428802), a scholarship from the National Natural Science Foundation of China (41402213), the Open Fund of Three Gorges Research Center for Geo-hazard, Ministry of Education, China University of Geosciences (TGRC201403), and the Key Laboratory of Groundwater Contamination and Remediation, China Geological Survey (CGS) and Hebei Province (KF201508). Thanks to all members who participated in the field work and who offered helpful advice for this study.

Author Contributions: This research was carried out by all authors. Qinghua Wu and Guiling Wang designed the experiments together; Qinghua Wu performed the experiments and wrote the draft of the paper. Wei Zhang1 and Haodong Cui made some comments and corrections; Wei Zhang2 analyzed the data of experiments.

Conflicts of Interest: The authors declare no conflict of interest.

\section{References}

1. Fei, Y.; Zhang, Z.; Zhang, F.E.; Wang, Z; Chen, Z.; Chen, J.; Qian, Y.; Li, Y. An analysis of influence of human activity and climate change on water resources of the North China Plain. Acta Geosci. Sin. 2007, 28, 567-571.

2. Jun, X.I. A perspective on hydrological base of water security problem and its application study in North China. Prog. Geogr. 2002, 21, 517-526.

3. Jin, M.; Zhang, R.; Sun, L.; Gao, Y. Temporal and spatial soil water management: A case study in the Heilonggang region, PR China. Agric. Water Manag. 1999, 42, 173-187. [CrossRef]

4. Vries, J.J.D.; Simmers, I. Groundwater recharge: An overview of processes and challenges. Hydrogeol. J. 2002, 10, 5-17. [CrossRef]

5. Scanlon, B.R.; Healy, R.W.; Cook, P.G. Choosing appropriate techniques for quantifying groundwater recharge. Hydrogeol. J. 2002, 10, 18-39. [CrossRef]

6. Cervi, F.; Corsini, A.; Doveri, M.; Mussi, M.; Ronchetti, F.; Tazioli, A. Characterizing the recharge of fractured aquifers: A case study in a flysch rock mass of the northern Apennines (Italy). Eng. Geol. Soc. Territ. 2014, 3, 563-567.

7. Ma, J.Z.; Ding, Z.; Gates, J.B.; Su, Y. Chloride and the environmental isotopes as the indicators of the groundwater recharge in the Gobi Desert, northwest China. Environ. Geol. 2008, 55, 1407-1419. [CrossRef]

8. Lo, S.; Zavattaro, L.; Acutis, M.; Maria, G. Chloride profile technique to estimate water movement through unsatured zone in a cropped area in subhumid climate (Po Valley-NW Italy). J. Hydrol. 2003, 270, 65-74.

9. Novotny, E.V.; Sander, A.R.; Mohseni, O.; Stefan, H.G. Chloride ion transport and mass balance in a metropolitan area using road salt. Water Resour. Res. 2009, 45, 1-13. [CrossRef]

10. Subyani, A.M. Use of chloride-mass balance and environmental isotopes for evaluation of groundwater recharge in the alluvial aquifer, Wadi Tharad, western Saudi Arabia. Environ. Geol. 2004, 46, 741-749. [CrossRef]

11. Ting, C.S.; Kerh, T.F.; Liao, C.J. Estimation of groundwater recharge using the chloride mass-balance method, Pingtung Plain, Taiwan. Hydrogeol. J. 1998, 6, 282-292. [CrossRef]

12. Zagana, E.; Obeidat, M.; Kuells, C.; Udluft, P. Chloride, hydrochemical and isotope methods of groundwater recharge estimation in eastern Mediterranean areas: A case study in Jordan. Hydrol. Process. 2007, 21, 2112-2123. [CrossRef]

13. Scanlon, B.R. Evaluation of liquid and vapor water flow in desert soils based on chlorine 36 and tritium tracers and nonisothermal flow simulations. Water Resour. Res. 1992, 28, 285-297. [CrossRef] 
14. Flint, A.L.; Flint, L.E.; Kwicklis, E.M.; Fabryka-martin, J.T.; Bodvarsson, G.S. Estimating recharge at Yucca Mountain, Nevada, USA: Comparison of methods. Hydrogeol. J. 2002, 10, 180-204. [CrossRef]

15. Dassi, L. Use of chloride mass balance and tritium data for estimation of groundwater recharge and renewal rate in an unconfined aquifer from North Africa: A case study from Tunisia. Environ. Earth Sci. 2010, 60, 861-871. [CrossRef]

16. Wang, B.G.; Jin, M.G.; Wang, W.; Nimmo, J.R.; Yang, L. Estimating groundwater recharge in Hebei Plain, China under varying land use practices using tritium and bromide tracers. J. Hydrol. 2008, 356, 209-222. [CrossRef]

17. Aquilanti, L.; Clementi, F.; Nanni, T.; Palpacelli, S.; Tazioli, A.; Vivalda, P.M. DNA and fluorescein tracer tests to study the recharge, groundwater flowpath and hydraulic contact of aquifers in the Umbria-Marche limestone ridge (central Apennines, Italy). Environ. Earth Sci. 2016, 75, 5436-5441. [CrossRef]

18. Bitterlich, S.; Durner, W.; Iden, S.C.; Knabner, P. Inverse estimation of the unsaturated soil hydraulic properties from column outflow experiments using free-form parameterizations. Vadose Zone J. 2004, 3, 971-981. [CrossRef]

19. Iden, S.C.; Durner, W. Free-form estimation of the unsaturated soil hydraulic properties by inverse modeling using global optimization. Water Resour. Res. 2007, 43, 1-12. [CrossRef]

20. Gogolev, M. Assessing groundwater recharge with two unsaturated zone modeling technologies. Environ. Geol. 2002, 42, 248-258. [CrossRef]

21. Bethune, M.G.; Selle, B.; Wang, Q.J. Understanding and predicting deep percolation under surface irrigation. Water Resour. Res. 2008, 44, 1-16. [CrossRef]

22. Jiménez-Martínez, J.; Skaggs, T.H.; van Genuchten, M.T.; Candela, L. A root zone modelling approach to estimating groundwater recharge from irrigated areas. J. Hydrol. 2009, 367, 138-149. [CrossRef]

23. Mattern, S.; Vanclooster, M. Estimating travel time of recharge water through a deep vadose zone using a transfer function model. Environ. Fluid Mech. 2010, 10, 121-135. [CrossRef]

24. Lu, X.H.; Jin, M.G.; van Genuchten, M.T.; Wang, B.G. Groundwater recharge at five representative sites in the Hebei Plain, China. Ground Water 2011, 49, 286-294. [CrossRef] [PubMed]

25. Scott, R.L.; Shuttleworth, W.J.; Keefer, T.O.; Warrick, A.W. Modeling multiyear observations of soil moisture recharge in the semiarid American Southwest. Water Res. 2000, 36, 2233-2247. [CrossRef]

26. An, Y.; Li, Y. Change of Evaporation in Recent 50 years in Heibei. J. Arid Land Resour. Environ. 2005, 19, 159-162.

27. Urbanc, J.; Leis, A. Tracing of water movement through the unsaturated zone of a coarse gravel aquifer by means of dye and deuterated water. Environ. Geol. 2007, 51, 1401-1412.

28. Lappan, R.E.; Hrymak, A.N.; Pelton, R. Dependence of in situ precipitate deposition on flow characteristics in multi-permeability porous media. Chem. Eng. Sci. 1997, 52, 2963-2975. [CrossRef]

29. Ritter, A.; Hupet, F.; Mun, R.; Lambot, S.; Vanclooster, M. Using inverse methods for estimating soil hydraulic properties from field data as an alternative to direct methods. Agric. Water Manag. 2003, 59, 77-96. [CrossRef]

30. Silva, O.; Carrera, J.; Dentz, M.; Kumar, S.; Alcolea, A.; Willmann, M. A general real-time formulation for multi-rate mass transfer problems. Hydrol. Earth Syst. Sci. 2009, 13, 1399-1411. [CrossRef]

31. Šimůnek, J.; Šejna, M.; Saito, H.; Sakai, M.; van Genuchten, M.T. The HYDRUS-1D Software Package for Simulating the One-Dimensional Movement of Water, Heat, and Multiple Solute in Variably-Saturated Media; version 4.08; Department of Environmental Sciences, University of California Riverside: Riverside, CA, USA, 2009.

32. Wu, Q.; Zhang, W.; Ling, W.; Wang, G. Study on soil water dynamics evolvement law under straw mulch condition. Agric. Res. Aird Areas 2009, 27, 76-82.

33. Genuchten, V. A closed-form equation for predicting the hydraulic conductivity of unsaturated soils. Soil Sci. Soc. Am. J. 1980, 44, 892-898. [CrossRef]

34. Inoue, M.; Šimůnek, J.; Hopmans, J.W.; Clausnitzer, V. In situ estimation of soil hydraulic functions using a multistep soil-water extraction technique. Water Resour. 1998, 34, 1035-1050. [CrossRef]

35. Kelleners, T.J.; Soppe, R.W.O.; Ayars, J.E.; Šimůnek, J.; Skaggs, T.H. Inverse analysis of upward water flow in a groundwater table lysimeter. Vadose Zone J. 2005, 4, 558-272. [CrossRef]

36. Alcalá, F.J.; Custodio, E. Atmospheric chloride deposition in continental Spain. Hydrol. Process. 2008, 22, 3636-3650. [CrossRef] 
37. Liu, J.; Chen, Z.; Zhang, Z.; Fei, Y.; Zhang, F.; Chen, J.; Wang, Z. Estimation of natural groundwater recharge in the Hutuo river alluvial-proluvial fan using environmental tracers. Geol. Sci. Technol. Inf. 2009, 28, 114-118.

38. Wang, S.F.; Zhang, X.Y.; Pei, D. Impacts of different water supplied conditions on root distribution, yield and water utilization efficiency of winter wheat. Trans. CSAE 2006, 22, 27-32.

39. Ying, Z.X. A review of agricultural water-saving research at Luancheng Agro-Ecosystem Experimental Station of Chinese Academy of Sciences over the last 30 years. Chin. J. Eco-Agric. 2011, 19, 987-996.

40. Chen, M. Adsorption of main anions in variable charge soil. Chin. J. Soil Sci. 1994, 25, 46-49.

41. Shao, Z.; Zhao, M.; Li, Q.; Ji, G. Metal cation-induced $\mathrm{Cl}^{-}$adsorption by soils. Environ. Chem. 2003, 22, 1-8.

42. Porro, I.; Wierenga, P.W. Transient and steady-state solute transport through a large unsaturated soil column. Ground Water 1993, 31, 193-200. [CrossRef]

43. Huyer, W.; Neumaier, A. Global optimization by multilevel coordinate search. J. Glob. Optim. 1999, 14, 331-355. [CrossRef]

44. Lambot, S.; Javaux, M.; Hupet, F.; Vanclooster, M. A global multilevel coordinate search procedure for estimating the unsaturated soil hydraulic properties. Water Resour. Res. 2002, 38, 1-15. [CrossRef]

45. Šimůnek, J.; van Genuchten, M.T.; Wendroth, O. Parameter estimation analysis of the evaporation method for determining soil hydraulic properties. Soil Sci. Soc. Am. J. 1995, 62, 894-905. [CrossRef]

46. Wu, Q. Quantifying Preferential Flow for the Soil Water Infiltration; Chinese Academy of Geological Sciences: Beijing, China, 2013.

(C) 2016 by the authors; licensee MDPI, Basel, Switzerland. This article is an open access article distributed under the terms and conditions of the Creative Commons Attribution (CC-BY) license (http://creativecommons.org/licenses/by/4.0/). 